\title{
Notes
}

\section{Discovery of one of Sir John Franklin's ships}

\section{William Barr}

Arctic Institute of North America, University of Calgary, Calgary AB T2N 1N4, Canada (wbarr@ucalgary.ca)

Received September 2014; first published online 15 October 2014

doi:10.1017/S0032247414000758

In the summer of 2014 a major search was mounted in the Canadian Arctic for H.M.S. Erebus and Terror, the ships of Sir John Franklin's expedition, the aim of which was to make a transit of the northwest passage. Beset in the ice to the northwest of King William Island in the summer of 1846, they were abandoned there by the 105 surviving members of their crews in the summer of 1848 . The officers and men hoped to walk south to the mouth of the Back River, presumably to ascend that river in the hope of reaching the nearest Hudson's Bay Company's post at Fort Resolution on Great Slave Lake. None of them survived. The 2014 expedition, the Victoria Strait Expedition, mounted by a consortium which included Parks Canada, the Canadian Coast Guard, the Canadian Navy, the Royal Canadian Geographical Society, the Arctic Research Foundation, and One Ocean Adventure, had four ships at its disposal including the Canadian Coast Guard's icebreaker Sir Wilfrid Laurier (Captain Bill Noon) and the Navy's HMCS Kingston.

The Victoria Strait Expedition encountered very heavy ice in its proposed search area to the northwest of King William Island and hence shifted its focus further south to the southeast corner of Queen Maud Gulf. On 1 September Scott Youngblood, a scientist with the Canadian Hydrographic Service took off by helicopter from the Sir Wilfrid Laurier and landed on a small island, identified as Hat Island, to the northwest of O'Reilly Island and south of the Royal Geographical Society Islands. His aim was to establish a beacon and to determine its position by GPS in order to tie-in sounding traverses. In addition to the search for the Franklin ships the expedition also aimed at improving the hydrographic charts of the area. Since there were vacant seats on the helicopter, Doug Stenton, Director of Nunavut Heritage and Culture and Richard Park, a professor of Archaeology at the University of Waterloo, Ontario, joined Youngblood on the flight. On the island they and the helicopter pilot discovered a fork-shaped metal object, about $43 \mathrm{~cm}$ long, identified as part of a ship's davit, and a wooden hawse plug, both items bearing the Royal Navy's broad arrow symbol.

In view of this find the diving boat Investigator was lowered from the icebreaker to search the waters off the island. Investigator started towing a side-scan sonar tow-fish on a grid pattern off the island and almost immediately it revealed a remarkable image of a large wooden ship, lying upright on the sea-bed in a depth of $11 \mathrm{~m}$ of water. The ship appeared to be largely intact although her masts were missing. Next an ROV (remotely operated underwater vehicle) was lowered and over a period of about 40 minutes sent back remarkably clear images of the ship, including deck planking and cannon. Since Erebus and Terror were almost identical, it is impossible to say at this point which of them it is. This discovery was the result of two fortunate coincidences: the ice conditions further north which forced the expedition to focus its attention further south; and the accident of the archaeologists finding the two artefacts on the island, which helped to narrow the underwater search.

The two artefacts found on the island were sent south to Ottawa and were displayed to media at an event at which Prime Minister Stephen Harper announced the discovery of the ship on 9 September. On 11 September archaeologists MarcAndré Bernier and Ryan Harris of Parks Canada's underwater archaeology team, flew back north with full gear, to dive on the wreck before freeze-up.

Accounts of Inuit encounters with this and other exploration vessels have survived in the Inuit oral tradition down to the present. The first such account was recorded by McClintock (1859: 227); from Inuit near Cape Victoria, much farther north, he heard that one of Franklin's ships had been driven ashore by the ice in the marine area known as Ootgoolik, between Reilly Island and the Royal Geographical Society Islands. In the 1860's Charles Francis Hall heard from an Inuk whose name he rendered as Nuk-kee-che-uk, about a ship he had seen in the same area (Woodman 1991: 248-252). It was beset in first-year ice, and had four boats hanging in davits along its sides and one at the stern. A gangplank led from the deck down to the ice and the deck was housed over with canvas. The Inuit felt that a party of men had wintered on board the ship, and later tracks, undoubtedly not those of Inuit, were found on shore. Nuk-kee-che-uk and other Inuit went aboard, and made their way below. There they found the corpse of a large man, fully clothed, which smelled badly. They ransacked the ship for items they could use over a fairly lengthy period. Returning after some time, they found that the ship had sunk, although the masts still projected above the water .Subsequently large amounts of lumber and wreckage drifted ashore. Given the depth of water over the newly discovered wreck $(11 \mathrm{~m})$ this would help confirm the accuracy of the Inuit account. Much the same story was recounted by Inuit to Lt. Frederick Schwatka during his expedition of 1878-1880 (Gilder 1881: 79; Klutschak 1987: 131). The only possible explanation of one of Franklin's ships being in this location (since they were abandoned by both crews in the summer of 1848 , is that some members had returned to the ships, and had managed to sail one of them south.

Information as to how this vessel may have reached its final position has emerged quite recently. At some time between 1994 and 2008, at a meeting in Cambridge Bay, Victoria Island, Dorothy Eber recorded an interview with an Inuit elder, Frank Analok (Eber 2008: 85-86). He reported a story handed down over the decades, namely that a ship had wintered off the south coast of Imnguyaaluk, the most northerly large island of the Royal Geographical Society group. Some of her crew also appeared to have camped on shore. In the following summer the ship departed, and may possibly be the vessel that ended up off Hat Island.

\section{References}

Eber, D.H. 2008. Encounters on the passage. Inuit meet the explorers. Toronto: University of Toronto Press. 
Gilder, W.H. 1881. Schwatka's search. Sledging in the Arctic in quest of the Franklin records. New York: Charles Scribner's Sons.

Klutschak, H. 1987. Overland to Starvation Cove. With the Inuit in search of Franklin 1878-1880, (translator and editor, W. Barr). Toronto: University of Toronto Press.
McClintock, F.L. 1859. The voyage of the 'Fox' in the arctic seas. A narrative of the discovery of the fate of Sir John Franklin and his companions. London: John Murray.

Woodman, D.C. 1991. Unravelling the Franklin mystery. Inuit testimony. Montreal and Kingston: McGill-Queen's University Press.

\section{The Arctic Council after Kiruna Philip E. Steinberg}

Department of Geography, Durham University, Lower Mountjoy, South Road, Durham DH1 3LE

(steinbergphil@gmail.com)

\section{Klaus Dodds}

Department of Geography, Royal Holloway, University of London, Egham Hill, Egham TW20 0EX

\section{Received May 2013; first published online 13 August} 2013

doi:10.1017/S0032247413000557

ABSTRACT. This note considers the latest iterations to the Arctic Council following the May 2013 ministerial meeting in Kiruna, Sweden. While new state observers including China and Japan were admitted, the European Union's application was deferred and the entire list of non-governmental and intergovernmental organisation applicants was rejected without consideration. Although time-based pressures may have been a factor, the failure to consider the non-state entities' applications has the effect of reinforcing the impression that the Arctic Council is and will remain a state-centric body.

\section{Introduction}

After weeks of anticipation by Arctic watchers, the foreign ministers of the eight Arctic states met on 15 May 2013 in Kiruna, Sweden and admitted six new states, China, India, Italy, Japan, Singapore, and South Korea, to join the six states, nine intergovernmental organisations, and eleven non-governmental organisations that already had permanent observer status in the Arctic Council (AC). As Swedish foreign minister and meeting host Carl Bildt told The New York Times (16 May 2013), the expansion 'strengthens the position of the Arctic Council on the global scene.'

Other commentators inferred more nefarious motives behind the new entrants' desire to increase their Arctic presence. Implicitly fusing the perspectives of two early 20th century thinkers, Vilhjalmur Stefansson and Halford Mackinder, Mika Mered of the Washington-based Polariis consulting firm expressed the opinion: 'The Arctic in the 21st century will be the center of the world. If you control the Arctic, you control the world. . That is the real issue around the Chinese application to the Arctic Council' (Deutsche Welle 16 May 2013). But this was countered somewhat by Linda Jakobson's analysis in the London Financial Times (19 May 2013), in which she noted:

China's motives in the Arctic are perfectly comprehensible. First, melting Arctic ice will have a profound effect on northeast Asia's climate, perhaps harming agriculture. China is one of the most susceptible countries to rising sea levels because of its low-lying and vulnerable coast. Second, within 20 years the Northern Sea Route across the northern coast of Russia could offer an alternative way to transport goods from northeast Asia to Europe during summer. No country dependent on trade can ignore the possibility that traffic along the Arctic sea routes will increase substantially.
In fact, enlargement of the $\mathrm{AC}$ to include the six new permanent observer states, and, in particular, the four Asian shipping states, occurred only because it was understood that it would probably benefit the new entrants, the Arctic Council itself, and the eight AC member states. China, Japan, Singapore, and South Korea are well aware that the opening of Arctic sea lanes may some day transfigure commercial relations among the world's trading powers, and they have been positioning themselves accordingly, from making financial investments in icebreaking technology to making political investments in diplomatic fora. Although the International Maritime Organization is probably the most important institution for the promulgation of rules that will govern Arctic shipping, it seems likely that the AC, which has now adopted two binding resolutions on Arctic activities, will remain involved as well, and these major trading nations have an interest in being in the room, even if not at the table, when the rules are discussed. Conversely, any subsequent use of Arctic sea-lanes by Asian shippers would benefit the Arctic states, every one of which exports or seeks to export minerals, oil, or gas. Enhanced Arctic involvement by Asian shipping states also has the potential to bring new revenues to states such as Iceland that seek to become Arctic transhipment centres and to those such as Russia and Canada that seek to manage coastal portions of Arctic sea lanes. And, as Bildt noted, the involvement of key users (or potential users) of the Arctic, as well as those who control its land (the eight member-states) and live there (the six indigenous organisation permanent participants), would bolster the AC's status as the forum for working through issues pertaining to the region's environmental stewardship and economic development.

In short, while the admission of China and the other states as permanent observers has made for eye-catching headlines that play on popular notions of the Arctic as an exceptional space, the site of an anachronistic, and potentially explosive 'great game' in which states compete in a 'race for the riches' (for example Howard 2009), it seems to us that the main impact of AC expansion has been to make the Arctic less exceptional. That is, the Arctic is increasingly a region that, like other regions, has an institutional structure that encourages cooperation and consultation among states so as to facilitate commerce, and increasingly the $\mathrm{AC}$ is a crucial component of that institutional apparatus. Therefore, from our perspective, the most notable outcome of Kiruna was neither the admission of the six new permanent observer states nor the deferral of permanent observer status for the European Union nor the signing of the Agreement on Cooperation on Marine Oil Pollution Preparedness and Response. Rather, we focus here on an event that attracted almost no media attention: the AC's failure to act on the permanent observer status applications filed by seven non-governmental and intergovernmental organisations.

\section{To observe or not to observe}

15 May 2013 may have been the first (and last) time that Greenpeace and the Association of Oil and Gas Producers 